\title{
Are sugar-free confections really beneficial for dental health?
}

\author{
H. Nadimi, ${ }^{1}$ H. Wesamaa, ${ }^{2}$ S.-J. Janket, ${ }^{3}$ P. Bollu, ${ }_{1}^{4}$ and J. H. Meurman ${ }^{5}$
}

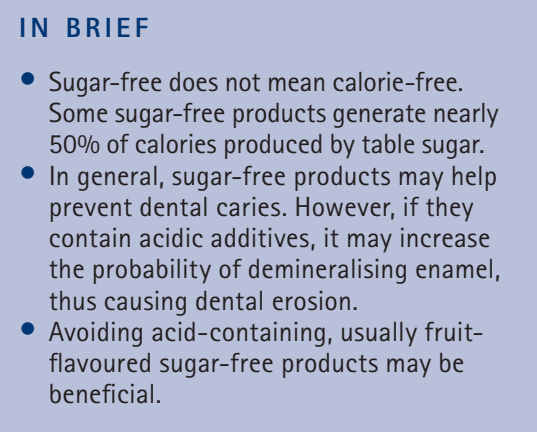

Background Various sugar substitutes have been introduced and are widely used in confections and beverages to avoid tooth decay from sugar and other fermentable carbohydrates. One group of sugar substitutes are sugar alcohols or polyols. They have been specifically used in foods for diabetic patients because polyols are not readily absorbed in the intestine and blood stream, preventing post-prandial elevation of glucose level. Additionally they may lower caloric intake. Methods We searched PubMed, Cochrane Controlled Trials Registry, Cochrane Oral Health Review, Centre for Reviews and Dissemination in the UK, National Library for Public Health and a Centre for Evidence Based Dentistry website up to the end of October 2010, using the search terms 'sugar alcohol' or 'sugar-free' or 'polyols' and combined with a search with terms 'dental caries' or 'dental erosion'. Results Xylitol, a polyol, has been approved by the US Food and Drug Administration for its non-cariogenic properties that actually reduce the risk of dental decay and recently, the European Union also officially approved a health claim about xylitol as a 'tooth friendly' component in chewing gums. Although the presence of acidic flavourings and preservatives in sugar-free products has received less attention, these additives may have adverse dental health effects, such as dental erosion. Furthermore, the term sugar-free may generate false security because people may automatically believe that sugar-free products are safe on teeth. Conclusion We concluded that polyol-based sugar-free products may decrease dental caries incidence but they may bring another dental health risk, dental erosion, if they contain acidic flavouring. There is a need for properly conducted clinical studies in this area.

\section{INTRODUCTION}

Dental caries is one of the most prevalent health issues affecting a large proportion of the world population and is considered to be the most common form of chronic disease among schoolchildren. In adults, untreated tooth decay is seen in $28 \%$ of people aged 35-44 and 18\% of people aged 65 years and older. ${ }^{1}$ Caries dates back over

\footnotetext{
Dental Student, ${ }^{3 *}$ Research Associate Professor in General Dentistry/Research Assistant Professor in Periodontology and Oral Biology, Henry M. Goldman School of Dental Medicine, Boston University, 100 East Newton Street, Boston, MA 02118, USA; Institute of Dentistry, University of Helsinki, Fl-00014, Helsinki, Finland; ${ }^{4}$ Assistant Professor and Research Coordinator, College of Dental Medicine, University of Southern Nevada, 11 Sunset Way, Henderson, NV 89014, USA: ${ }^{5}$ Professor of Oral Infectious Diseases, Institute of Dentistry, University of Helsinki/Department of Oral and Maxillofacial Diseases, Helsinki University Central Hospital, Helsinki, Finland

${ }^{*}$ Correspondence to: Dr Sok-Ja Janket

Email:skjanket@bu.edu
}

\section{Online article number E15}

Refereed Paper - accepted 7 April 2011

DOI: $10.1038 /$ sj.bdj.2011.823

${ }^{\circ}$ British Dental Journal 2011; 211: E15 a million years and caries is still widely observed in developing countries. ${ }^{2}$

Sugars and other fermentable dietary carbohydrates are substrates to microorganisms that ferment carbohydrates and generate acids. The acidity causes demineralisation of the tooth enamel which is the initial step in dental caries lesions. Hence, blocking any of the aetiological factors will decrease caries activity. These include suppressing acidogenic bacteria in the mouth by maintaining good oral hygiene and limiting consumption of fermentable carbohydrates. In addition, use of fluoride, which reduces enamel liability to acid dissolution, leads to less dental caries. ${ }^{3}$

Sugar substitutes have been introduced and widely investigated in limiting the dietary source of caries hazards. ${ }^{4}$ Of these, the sugar alcohol polyols are most popular today in many foods and beverages. Most notably, they have been used in chewing gums and candies as well as in soft drinks and sports drinks. Furthermore, polyols are less likely to exacerbate diabetes because these molecules are not readily absorbed into the blood stream. ${ }^{5}$

Sugar alcohols produce less acid from fermentation of carbohydrate by oral microbiota. ${ }^{6}$ Any acidity surrounding the tooth, especially a $\mathrm{pH}$ below the critical value of approximately $\mathrm{pH} 5.5$ of dental enamel, may induce chemical dissolution or erosion. ${ }^{7,8}$ Dental erosion is a slowly progressing condition described as the irreversible loss of dental hard tissue due to a chemical process without involvement of microorganisms. ${ }^{9}$

Acids are frequently added as flavouring and preservative agents in confections and beverages but their role in dental health has not been thoroughly studied. ${ }^{10}$ Depending on whether the acidic compound is in liquid or solid form, the location of dental defects may differ. Acidic liquids preferentially seem to cause erosion of the anterior maxillary and mandibular teeth. Erosion from solid acids such as in candies manifests mainly on posterior teeth with smooth, silky-glazed 
appearance of enamel and cupping of the occlusal surfaces of posterior teeth. ${ }^{10}$

In comparison to what is known about the fermentation of sucrose and other fermentable sugars, data regarding oral health consequences of polyols are sparse. The present review is mainly based on a PubMed literature search up to the end of October 2010 resulting in the collection of 471 references with the keywords 'sugar alcohol' or 'sugar free' or 'polyols' and combined with a search using the terms ‘dental caries' or 'dental erosion'. We also searched Cochrane Controlled Trials Registry, Cochrane Oral Health Review, Centre for Reviews and Dissemination in the UK, American Dental Association Library and National Library for Public Health, and a Centre for Evidence Based Dentistry (CEBD) website, but did not find any additional literature. The lack of well-conducted studies or randomised trials on the topic prohibited us from conducting a meta-analysis and quantifying dental erosion. The review is thus mainly descriptive.

\section{POLYOLS}

Polyols are naturally found in fruits and vegetables but are also manufactured from inorganic sources. ${ }^{5}$ Polyols are hydrogenated forms of carbohydrates whose carbonyl group has been reduced to primary or secondary hydroxyl group with structural similarities to sugars and/or alcohols. Polyols are typically used in conjunction with other artificial sweeteners because they tend to have lower sweetness than natural sugars. Some of the common sugar alcohols include xylitol (5-carbon sugar alcohol), sorbitol (6-carbon sugar alcohol), maltitol (12-carbon sugar alcohol), mannitol (6-carbon sugar alcohol), and isomalt (12-carbon sugar alcohol).

The primary indication for polyols has been in the production of foods for people suffering from diabetes because unlike sugars, polyols are not readily absorbed in the intestine. This prevents post-prandial fluctuation of the blood glucose levels and helps in achieving lower caloric intake. However, polyols are not calorie-free, as shown in Table 1. Sorbitol generates nearly $65 \%$ of the calories from the same amount of sucrose, and the lowest calories are generated by lactitol and isomalt, with $50 \%$ of the calories that sucrose generates.
Therefore, high levels of polyol intake may still have deleterious effects on the blood sugar level although to a lesser extent than other caloric sweeteners. In addition, because polyols are not well-absorbed in the intestine, accumulation of unabsorbed polyols may cause gastro-intestinal disturbance and osmotic diarrhoea, which is not within the scope of this review.

\section{Polyols and oral health}

There have been particularly many studies analysing the effects of xylitol in chewing gum. ${ }^{11-13}$ Xylitol has been approved by the U.S. Food and Drug Administration (FDA) for its non-cariogenic properties that actually reduce the risk of dental decay. ${ }^{14}$ Recently, the European Commission also approved a health claim of xylitol on 'tooth friendliness' when used in chewing gum. ${ }^{15}$

Oral bacteria are unable to ferment xylitol. Studies have also shown that xylitol chewing gum can increase salivary flow leading to improved buffering effects of the saliva. ${ }^{16}$ Furthermore, xylitol has the ability to reduce the growth of oral bacteria by inhibiting glycolysis. When xylitol is taken up by oral bacteria, it is incorporated as xylitol 5-phosphate which inhibits the enzymes involved in metabolism. ${ }^{17}$ Sugar alcohols have been termed as nonfermentable sugars in the literature, yet some oral bacteria can metabolise certain sugar alcohols. ${ }^{18}$ For example, maltitol and sorbitol appear to have variable fermentability depending on the species of bacteria involved. Among polyols, scientific evidence indicates that xylitol demonstrates the strongest caries prevention effect. ${ }^{19,20}$

The oral microorganism that displays strong acidogenicity is Streptococcus mutans. ${ }^{21}$ Unlike other species of the viridans streptococci family, S. mutans is capable of fermenting mannitol and sorbitol. ${ }^{22}$ Lyon showed the various types of carbohydrates that can be metabolised by $S$. mutans and other strains of microorganisms. ${ }^{11}$ He also showed that $S$. mutans ferments mannitol but not xylitol. Thus, xylitol shows superior anticariogenic properties in this regard. ${ }^{11}$

There are three notable properties of xylitol that have made it an important sugar alcohol in the dental perspective: 1) xylitol is not readily fermented by oral bacteria, especially by streptococci; 2) it

\begin{tabular}{|c|c|}
\hline Name & Caloric content $(\mathrm{kcal} / \mathrm{g})$ \\
\hline Sucrose & 4 \\
\hline Sorbitol & 2.6 \\
\hline Mannitol & 1.6 \\
\hline Maltitol & 2.1 \\
\hline Lactitol & 2 \\
\hline Xylitol & 2.4 \\
\hline Isomalt & 2 \\
\hline \multicolumn{2}{|c|}{$\begin{array}{l}\text { Source: Food Insight sugar alcohols factsheet. Available } \\
\text { at http://www.foodinsight.org/Resources/Detail. } \\
\text { aspx?topic=Sugar_Alcohols_Fact_Sheet }\end{array}$} \\
\hline
\end{tabular}

has been shown to reduce the numbers of $S$. mutans in the oral cavity by limiting the source of fermentable substrates for their survival; and 3) xylitol can induce the production of salivary enzymes which lead to the growth inhibition of bacteria in plaque. ${ }^{13}$ Together, these mechanisms are important in reducing dental caries incidence in patients. The effective dose of xylitol appears to be between $6.44 \mathrm{~g}$ and $10.32 \mathrm{~g}$ xylitol per day. Furthermore, lower doses of xylitol have also been shown to be efficient in caries prevention. ${ }^{23,24}$

The most commonly used polyol in several sugar-free chewing gums in the United States, however, is sorbitol. This is mainly due to its low cost compared to xylitol. ${ }^{25}$ Since sorbitol is fermented by mutans streptococci, thereby increasing the acid production in plaque, it should be considered low-cariogenic rather than non-cariogenic. ${ }^{26}$ Animal studies have also shown that microorganisms can learn to metabolise sorbitol when the fermentable sugar supply is restricted..$^{27}$

\section{EVIDENCE OF CARIES REDUCTION}

\section{Clinical trials with xylitol}

The effect of xylitol chewing gum has been extensively studied over the past 30 years. ${ }^{28}$ Blocking the early motherchild transmission of $S$. mutans is also an important step in caries prevention since the early $S$. mutans colonisation is connected with early childhood caries. The effect of maternal use of xylitol chewing gum on caries and on mutans streptococci in children has been shown to be beneficial in caries reduction, with significantly less 
S. mutans colonisation and less caries in the children. ${ }^{24,29}$

The use of xylitol products has also been tested on patients with high caries risk, with fixed orthodontic appliances, disabled school children and/or veterans with high root caries risk. ${ }^{30-32}$ Xylitol appeared to have caries preventive effects in all but one of these studies. However, in a two-year double blind trial evaluating the effect of xylitol- and xylitol/fluoride-containing lozenges on proximal caries, no statistically significant differences were found in caries incidence between the experimental groups and a control group that did not receive lozenges. ${ }^{33}$

Milk for neonates would be a natural vehicle for administration of anticaries compounds. Hence, the taste of xylitol in milk as a first step toward measuring the effectiveness of xylitol-containing milk on caries was tested in Peruvian children. ${ }^{34}$ The xylitol-sweetened milk appeared to be well accepted, offering a novel means for administration. However, we question the wisdom of introducing sweet taste sensation at an early age which may not be beneficial.

\section{Clinical trials with sorbitol}

Sorbitol is the most commonly used polyol in the United States because of its low cost. However, only a few clinical trials have been conducted on its caries-inhibitory action. Some trials have been conducted with xylitol, sorbitol, and mixtures of xylitol and sorbitol. According to the review by Burt, chewing sorbitol-sweetened gum no more than three times a day had low cariogenicity compared to chewing sugar-sweetened gum. ${ }^{25}$ Although small amounts of sorbitol can be fermented by oral microorganisms, this amount does not lower the plaque $\mathrm{pH}$ enough to cause demineralisation of enamel. ${ }^{35}$ In a rat model, however, an adaptation to sorbitol did take place and resulted in an enhanced drop in plaque $\mathrm{pH}$ following sorbitol application. ${ }^{27}$

\section{Caries reduction with other polyols}

Lactitol and maltitol have been tested mainly in laboratory animals. Lactitol, a lactose-based sugar alcohol, showed antidental caries properties similar to xylitol. ${ }^{36}$ However, since it is made from lactose and whey, lactose-intolerant persons may experience gastric disturbance. Maltitol was not utilised by mutans streptococci, nor did it produce sufficient acid to demineralise tooth enamel. Replacement of sucrose with maltitol in the diet resulted in a trend towards caries reduction. ${ }^{37}$ More recently, Mäkinen and co-workers compared the effects of erythritol, a tetritol (4-carbon sugar alcohol), with xylitol and D-glucitol (a 6-carbon sugar alcohol) on the risk of dental caries. ${ }^{38}$ The use of erythritol and xylitol resulted in a statistically significant reduction in the plaque and saliva levels of $S$. mutans ( $p<0.001$ in most cases) and there was also a significant reduction in the amount of dental plaque in groups receiving erythritol and xylitol. Further studies are needed, however, to verify these results.

\section{EVIDENCE OF HIDDEN RISK}

\section{Acids in sugar-free candies and beverages}

Addition of other ingredients such as acids to produce an enjoyable taste is another important aspect of sugar-free candies and beverages. Acids are also used in foods as preservatives. From a dental health point of view, acidic flavouring agents have the same detrimental effects on dental enamel as the microorganism-generated acids from sugar fermentation. This is evidenced by the demineralisation observed in vitro studies ${ }^{39}$ and also shown following the consumption of sugar-free beverages. The effect of acids in sugar-free products has yet to be widely studied in vivo, and more studies are needed in this area of research. Our literature review will next expand to dental erosion by discussing the acids added to sugar-free products in this perspective.

\section{Dental erosion}

When a patient presents with dental erosion, the possibility of frequent consumption of acidic candies should be considered as a potential detrimental aetiologic factor. The risk of erosion from acidic additives in sugar-free products has been recognised as early as 1978 by Kleber and colleagues. ${ }^{40}$ This phenomenon may be more apparent in paediatric patients due to low salivary volume. ${ }^{41}$ Recently a few in vivo, ex vivo and in vitro studies have been published on confections, confirming their erosive capacity. ${ }^{10,41-45}$ According to the study by
Wagoner and co-workers, both original flavour and sour versions of candies were potentially erosive; generally the erosive capacity was directly proportional to the acidity of the candies investigated..$^{45}$

In a study by Brand and co-workers, the erosive potential of several lollipops and the protective effect of saliva were investigated. Ten healthy volunteers consumed different types of lollipops and their salivary flow rate and $\mathrm{pH}$ was determined. The lollipops differed in their erosive potential depending on their flavours. Fruit and cola flavoured lollipops had a very low $\mathrm{pH}$ of 2.3-2.4 and showed a drop in the salivary $\mathrm{pH}$ to well below the critical value of 5.5. Strawberry yoghurt and salty liquorice lollipops had $\mathrm{pH}$ values of 3.8-4.7 and also resulted in a salivary $\mathrm{pH}$ below $5.5 .{ }^{43}$ Hence these products appeared to be potentially detrimental to the teeth. ${ }^{46}$

Candies are also made in spray-form in Europe and some chewing gums are filled with acidic centers. ${ }^{41,42}$ The seven candy sprays tested by Gambon and co-workers had an extremely low $\mathrm{pH}$ of 1.9-2.3. All these candy sprays had erosive potential and the effect may be even greater with children as their salivary volume is smaller than in adults. ${ }^{41}$ Also the longer exposure time to these acids may increase the risk of erosion even more. ${ }^{47}$ The acidic filling of a chewing gum reduced the microhardness of both primary and permanent enamel in a study by Bolan et al. Sour sweets have been found to be even more erosive than orange juice, which is a well-known erosive agent. ${ }^{10}$

Since dental erosion is an irreversible pathology and erosive lesions on teeth are difficult to treat, the addition of protective ingredients such as calcium and/or phosphate to candies has been considered. The addition of calcium has been shown to reduce the erosive tendency of potentially erosive candies. ${ }^{44,48}$ Salivary calcium concentration of around $15 \mathrm{mmol} / \mathrm{l}$ resulted in considerable attenuation in the erosive potential of a candy compared to candies without calcium ( $p<0.001){ }^{44}$ However, one recent study did not observe any protection against erosion by adding various minerals. ${ }^{49}$ The exact quantification of the possible protective effect of adding calcium into potentially erosive candies should be conducted in the future. The erosive potential of a foodstuff 
is the result of complex interactions of many molecules where calcium chelating properties are only one parameter. ${ }^{50}$ Table 2 presents studies where acidic products have been tested in relation to dental erosion.

\section{SUMMARY}

As the use of sorbitol and xylitol containing products increases, the public should be educated on the hidden risk of dental erosion due to acidic additives as well as the adverse effects of gastric disturbance and osmotic diarrhoea. Especially in sugarfree products, these adverse effects may be more insidious because the public has blind confidence that they are oral health friendly. Also, the exposure time to such products should be considered. Thus, hard candies or lollipops may be more harmful if they are slowly melted in the mouth than candy spray. ${ }^{47}$

Adding calcium and phosphate to the product is a promising approach to counteract the adverse erosive effect on teeth but more studies are needed to confirm its efficacy. At present, the reports of protective effects of fluoride against dental erosion are conflicting. Thus, we defer further discussion until a clear trend emerges.

In general, sugar-free products appear to be beneficial as far as dental caries is concerned. However, the unrecognised risk of acidic flavouring in sugar-free candies and beverages on dental health calls for more studies and public awareness. Based on research results by Kleber and Wagoner, acidic additives lower the $\mathrm{pH}$ of saliva well below the critical level of 5.5, regardless of acid type (Fig. 1). Some researchers advocate future randomized, cross-over trials. However, it may be unethical to expose study subjects to irreversible harm from dental erosion. Thus, future studies should include in vivo assessment of $\mathrm{pH}$ change with the consumption of sugar-free confections with and without acidic flavouring and ex vivo assessment of erosion at such respective $\mathrm{pH}$ levels.

\section{CONCLUSIONS}

Although some disagreement exists, results from numerous studies have shown that substitution of table sugar with sugarfree sweeteners is a healthier choice for dental caries prevention. However, the

\begin{tabular}{|c|c|c|c|c|}
\hline Type of study & Test subject/object & Main result & Comments & Reference \\
\hline $\begin{array}{l}\text { In vitro, } \\
\text { acidulants }\end{array}$ & Bovine incisors & $\begin{array}{l}\text { Fumaric acid, tar- } \\
\text { taric acid and citric } \\
\text { acid showed high- } \\
\text { est demineralisa- } \\
\text { tion. There was less } \\
\text { erosion when these } \\
\text { acids were given in } \\
\text { sorbitol candy. }\end{array}$ & $\begin{array}{l}\text { Enamel dissolution } \\
\text { was correlated } \\
\text { with the potential } \\
\text { of the acids to } \\
\text { chelate calcium. }\end{array}$ & Kleber et al. ${ }^{40}$ \\
\hline $\begin{array}{l}\text { Ex vivo and } \\
\text { in vitro, } \\
\text { beverages }\end{array}$ & Five healthy women & $\begin{array}{l}\text { Citric acid was the } \\
\text { most detrimental } \\
\text { to enamel. }\end{array}$ & $\begin{array}{l}\text { All drinks had a pH } \\
\text { of below } 5.5 \text {. }\end{array}$ & $\begin{array}{l}\text { Meurman } \\
\text { et al. }\end{array}$ \\
\hline $\begin{array}{l}\text { Ex vivo, } \\
\text { beverages }\end{array}$ & $\begin{array}{l}\text { Bovine tooth } \\
\text { enamel }\end{array}$ & $\begin{array}{l}\text { Most erosion } \\
\text { with cola, orange } \\
\text { beverage, sports } \\
\text { drink, orange juice, } \\
\text { diet cola. Fluoride } \\
\text { did not influence } \\
\text { erosive depth. }\end{array}$ & $\begin{array}{l}\text { Carbonated mineral } \\
\text { water, beer, coffee, } \\
\text { yoghurt and butter- } \\
\text { milk did not cause } \\
\text { surface erosion. } \\
\text { Lowest pH below } \\
4.5 \text {. }\end{array}$ & Rytömaa et al. ${ }^{39}$ \\
\hline $\begin{array}{l}\text { In vivo and } \\
\text { in vitro, } \\
\text { acidic candies }\end{array}$ & $\begin{array}{l}20 \text { healthy } \\
\text { volunteers }\end{array}$ & $\begin{array}{l}\text { Modified candy } \\
\text { reduced the erosive } \\
\text { potential of acidic } \\
\text { candies }\end{array}$ & $\begin{array}{l}\text { Critical pH may not } \\
\text { fully reflect when } \\
\text { dental erosion is } \\
\text { expected to occur. }\end{array}$ & $\begin{array}{l}\text { Jensdottir } \\
\text { et al. }\end{array}$ \\
\hline $\begin{array}{l}\text { In vitro, } \\
\text { sour candies }\end{array}$ & $\begin{array}{l}28 \text { different sour } \\
\text { candies }\end{array}$ & $\begin{array}{l}\mathrm{pH} \text { for all below } 4.0 \text {, } \\
\text { some to } 1.6 \text { and } 1.8\end{array}$ & $\begin{array}{l}\text { Primary teeth } \\
\text { are more prone } \\
\text { to erosion, soft } \\
\text { tissue irritation } \\
\text { was possible. }\end{array}$ & Robyn et al..$^{50}$ \\
\hline $\begin{array}{l}\text { In vitro, acidic } \\
\text { centre-filled } \\
\text { chewing gum }\end{array}$ & 80 enamel blocks & $\begin{array}{l}\text { The acidic filling } \\
\text { of gum reduced } \\
\text { the microhardness } \\
\text { of enamel }\end{array}$ & $\begin{array}{l}\text { Both primary and } \\
\text { permanent enamel } \\
\text { were affected }\end{array}$ & Bolan et al. ${ }^{42}$ \\
\hline $\begin{array}{l}\text { In vitro, } \\
\text { lollipops }\end{array}$ & $\begin{array}{l}10 \text { healthy } \\
\text { volunteers }\end{array}$ & $\begin{array}{l}\text { Lollipops differ in } \\
\text { erosive potential }\end{array}$ & $\begin{array}{l}\text { Fruit and cola } \\
\text { flavoured lollipops } \\
\text { have the greatest } \\
\text { erosive effect. }\end{array}$ & $\begin{array}{l}\text { Brand et al. } \\
2009^{51}\end{array}$ \\
\hline $\begin{array}{l}\text { In vivo and } \\
\text { in vitro, } \\
\text { candy sprays }\end{array}$ & $\begin{array}{l}\text { Seven different } \\
\text { candy sprays on } \\
\text { adult volunteers }\end{array}$ & $\begin{array}{l}\text { Candy sprays have } \\
\text { a very low pH of } \\
1.9-2.3\end{array}$ & $\begin{array}{l}\text { Effect on children } \\
\text { may be greater } \\
\text { as their salivary } \\
\text { volumes are smaller } \\
\text { than adults' }\end{array}$ & $\begin{array}{l}\text { Gambon et al. } \\
2009^{41}\end{array}$ \\
\hline
\end{tabular}

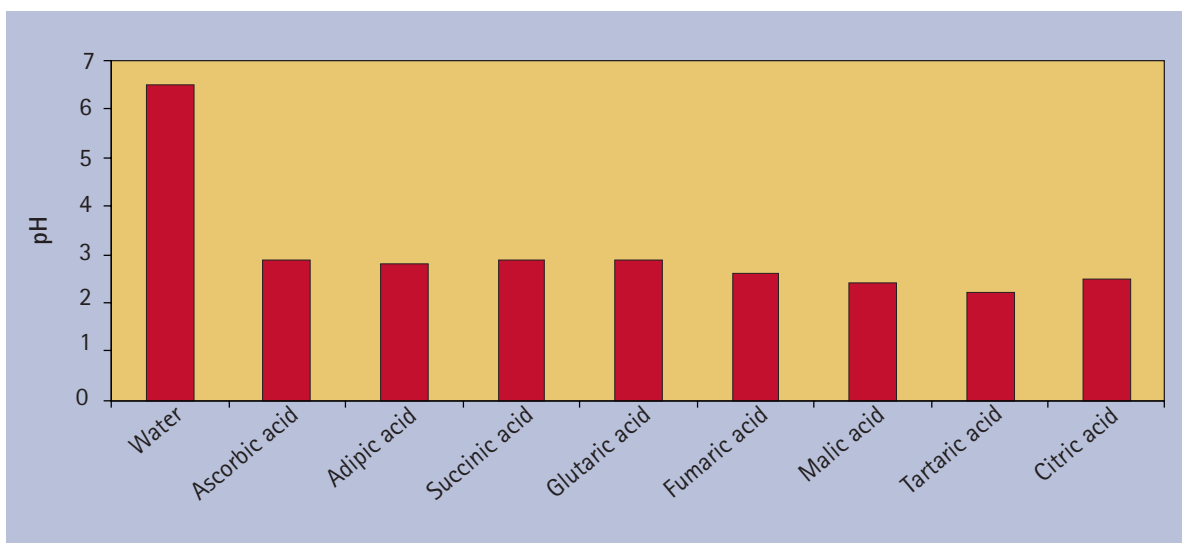

Fig. $1 \mathrm{pH}$ change with various acidic additives in sugar-free confections

acid flavouring and preservatives used in the sugar-free confections and beverages cause the salivary $\mathrm{pH}$ to drop below the critical value and thus may cause dental erosion. Therefore, properly conducted randomised controlled trials using sugarfree products with or without acidic additives are needed. 
1. Centers for Disease Control and Prevention. Preventing dental caries with community programs webpage. http://www.cdc.gov/OralHealth/publications/factsheets/dental_caries.htm (accessed 19 September 2011).

2. Zaborskis A, Milciuviene $S$, Narbutaite Bendoraitiene E, Kavaliauskiene A. Caries experience and oral health behaviour among 11-13-year-olds: an ecological study of data from 27 European countries, Israel, Canada and USA. Community Dent Health 2010; 27: 102-108.

3. World Health Organisation. Fluorides and oral health. Report of a WHO Expert Committee on Oral Health Status and Fluoride Use. World Health Organ Tech Rep Ser 1994; 846: 1-37.

4. Matsukubo T, Takazoe I. Sucrose substitutes and their role in caries prevention. Int Dent J 2006; 56: $119-130$.

5. Patra F, Tomar S K, Arora S. Technological and functional applications of low-calorie sweeteners from lactic acid bacteria. J Food Sci 2009; 74: R16-R23.

6. Kleinberg I. Oral effects of sugars and sweeteners. Int Dent J 1985; 35: 180-189.

7. Ericsson Y. Reduction of the solubility of ename surfaces. Acta Odontol Scand 1950; 9: 60-83.

8. Larsen M J, Pearce E I. Saturation of human saliva with respect to calcium salts. Arch Oral Biol 2003; 48: 317-322.

9. Lussi A, Portmann P, Burhop B. Erosion of abraded dental hard tissues by acid lozenges: an in situ study. Clin Oral Investig 1997; 1: 191-194.

10. Davies R, Hunter L, Loyn T, Rees J. Sour sweets: a new type of erosive challenge? Br Dent J 2008; 204: E3.

11. Lyon T C, Jr. Fermentation characteristics of strains of Streptococcus mutans. J Dent Res 1978; 57: 932.

12. Scheinin A, Makinen K K, Ylitalo K. Turku sugar studies. V. Final report on the effect of sucrose, fructose and xylitol diets on the caries incidence in man. Acta Odontol Scand 1976; 34: 179-216.

13. Makinen K K. Possible mechanisms for the cariostatic effect of xylitol. Int Z Vitam Ernahrungsforsch Beih 1976; 15: 368-380.

14. McNutt K. Sugar replacers and the FDA noncariogenicity claim. J Dent Hyg 2000; 74: 36-40.

15. European Commission. European Union Register of nutrition and health claims made on food - authorised health claims. Available at http://ec.europa. eu/food/food/labellingnutrition/claims/community_register/authorised_health_claims_en.htm (accessed 19 September 2011).

16. Hildebrandt G H, Sparks B S. Maintaining mutans streptococci suppression with xylitol chewing gum. J Am Dent Assoc 2000; 131: 909-916.

17. Trahan L. Xylitol: a review of its action on mutans streptococci and dental plaque - its clinical significance. Int Dent J 1995; 45: 77-92.

18. Edwardsson $S$, Birkhed D, Mejare B. Acid production from Lycasin, maltitol, sorbitol and xylitol by oral streptococci and lactobacilli. Acta Odontol Scand 1977; 35: 257-263.

19. Ly K A, Milgrom P, Rothen M. Xylitol, sweeteners, and dental caries. Pediatr Dent 2006; 28: 154-163.

20. Milgrom P, Ly K A, Roberts M C, Rothen M, Mueller G, Yamaguchi D K. Mutans streptococci dose response to xylitol chewing gum. J Dent Res 2006; 85: 177-181.

21. Fitzgerald R J, Keyes $P H$. Demonstration of the etiologic role of streptococci in experimental caries in the hamster. J Am Dent Assoc 1960; 61: 9-19.

22. Nisengard R J, Newman M G. Oral microbiology and immunology. Philadelphia, PA: W B Saunders Co, 1994.

23. Alanen P, Isokangas P, Gutmann K. Xylitol candies in caries prevention: results of a field study in Estonian children. Community Dent Oral Epidemiol 2000; 28: 218-224.

24. Thorild I, Lindau B, Twetman S. Salivary mutans streptococci and dental caries in three-year-old children after maternal exposure to chewing gums containing combinations of xylitol, sorbitol, chlorhexidine, and fluoride. Acta Odontol Scand 2004; 62: 245-250.

25. Burt B. The use of sorbitol- and xylitol-sweetened chewing gum in caries control. J Am Dent Assoc 2006; 137: 190-196.

26. van Loveren C. Sugar alcohols: what is the evidence for caries-preventive and caries-therapeutic effects? Caries Res 2004; 38: 286-293.

27. Firestone $A R$, Navia J $M$. In vivo measurements of sulcal plaque $\mathrm{pH}$ after topical applications of sorbitol and sucrose in rats fed sorbitol or sucrose. J Dent Res 1986; 65: 1020-1023.

28. Mäkinen K K. Sugar alcohols, caries incidence, and remineralization of caries lesions: a literature review. Int J Dent 2010; 2010: 981072. E-pub 2010 Jan 5.

29. Nakai Y, Shinga-Ishihara C, Kaji M, Moriya K Murakami-Yamanaka K, Takimura M. Xylitol gum and maternal transmission of mutans streptococci. J Dent Res 2010; 89: 56-60.

30. Makinen K K, Pemberton D, Makinen P L et al. Polyol-combinant saliva stimulants and oral health in Veterans Affairs patients - an exploratory study. Spec Care Dentist 1996; 16: 104-115.

31. Sengun A, Sari Z, Ramoglu S I, Malkoc S, Duran I. Evaluation of the dental plaque $\mathrm{pH}$ recovery effect of a xylitol lozenge on patients with fixed orthodontic appliances. Angle Orthod 2004; 74: 240-244.

32. Honkala E, Honkala S, Shyama M, Al-Mutawa S A. Field trial on caries prevention with xylitol candies among disabled school students. Caries Res 2006; 40: 508-513.

33. Stecksen-Blicks C, Holgerson P L, Twetman S. Effect of xylitol and xylitol-fluoride lozenges on approximal caries development in high-caries-risk children. Int J Paediatr Dent 2008; 18: 170-177.

34. Castillo J L, Milgrom P, Coldwell S E, Castillo R Lazo R. Children's acceptance of milk with xylitol or sorbitol for dental caries prevention. BMC Oral Health 2005; 5: 6.

35. Birkhed D, Edwardsson S, Kalfas S, Svensater G. Cariogenicity of sorbitol. Swed Dent J 1984;
8: $147-154$

36. Grenby T H, Phillips A. Dental and metabolic effects of lactitol in the diet of laboratory rats. Br J Nutr 1989; 61: 17-24.

37. Ooshima T, Izumitani A, Minami T et al. Noncariogenicity of maltitol in specific pathogenfree rats infected with mutans streptococci. Caries Res 1992; 26: 33-37.

38. Makinen K K, Saag M, Isotupa K P et al. Similarity of the effects of erythritol and xylitol on some risk factors of dental caries. Caries Res 2005; 39: 207-215.

39. Rytomaa I, Meurman J H, Koskinen J, Laakso T, Gharazi L, Turunen R. In vitro erosion of bovine enamel caused by acidic drinks and other foodstuffs. Scand J Dent Res 1988; 96: 324-333.

40. Kleber C J, Putt M S, Muhler J C. Enamel dissolution by various food acidulants in a sorbitol candy. J Dent Res 1978; 57: 447-451.

41. Gambon D L, Brand H S, Nieuw Amerongen A V. The erosive potential of candy sprays. Br Dent J 2009; 206: E20.

42. Bolan M, Ferreira M C, Vieira R S. Erosive effects of acidic center-filled chewing gum on primary and permanent enamel. J Indian Soc Pedod Prev Dent 2008; 26: 149-152.

43. Brand H S, Gambon D L, Van Dop L F, Van Liere LE, Veerman E C. The erosive potential of jawbreakers, a type of hard candy. Int J Dent Hyg 2010; 8: $308-312$.

44. Jensdottir T, Nauntofte B, Buchwald C, Bardow A. Effects of calcium on the erosive potential of acidic candies in saliva. Caries Res 2007; 41: 68-73.

45. Wagoner S N, Marshall T A, Qian F, Wefel J S. In vitro enamel erosion associated with commercially available original-flavour and sour versions of candies. J Am Dent Assoc 2009; 140: 906-913.

46. Meurman J H, Rytomaa I, Kari K, Laakso T, Murtomaa H. Salivary pH and glucose after consuming various beverages, including sugarcontaining drinks. Caries Res 1987; 21: 353-359.

47. Johansson A K, Lingstrom $P_{1}$ Imfeld $T$, Birkhed D. Influence of drinking method on tooth-surface $\mathrm{pH}$ in relation to dental erosion. Eur J Oral Sci 2004; 112: 484-489.

48. Barbour M E, Shellis R P, Parker D M, Allen G C, Addy M. Inhibition of hydroxyapatite dissolution by whole casein: the effects of $\mathrm{pH}$, protein concentration, calcium, and ionic strength. Eur J Oral Sci 2008; 116: 473-478.

49. Magalhaes A C, Moraes S M, Rios D, Wiegand A, Buzalaf M A. The erosive potential of 1\% citric acid supplemented by different minerals: an in vitro study. Oral Health Prev Dent 2010; 8: 41-45.

50. Robyn R L, Robert J M, John D R. Pucker up: the effects of sour candy on your patients' oral health. A review of the dental erosion literature and $\mathrm{pH}$ values for popular candies. Northwest Dent 2008; 87: 20-21, 24-25, 28-29 passim.

51. Brand H S, Gambon D L, Paap A, Bulthuis M S, Veerman E C, Amerongen A V. The erosive potential of lollipops. Int Dent J 2009; 59: 358-362. 